\title{
Patrik Törnudd (1935-2015) in memoriam
}

\section{Raimo Lahti}

Rättspolitiska forskningsinstitutets tidigare direktör, politices licentiat Patrik Törnudd avled vid 80-års ålder den 27 november 2015, nedbruten av en svår sjukdom. Han föddes 1 september 1935 i Helsingfors.

Törnudd tog studenten vid Svenska normallyceet år 1953. Sina akademiska studier avlade han vid Helsingfors universitet: politices magisterexamen år 1960 och politices licentiatexamen år 1971.

Patrik Törnudds första arbetsplats var under åren 1960-1963 Alkoholpolitiska forskningsinstitutet. Härifrån flyttade han till Kriminologiska forskningsinstitutet som löd under justitieministeriet och som senare blev Rättspolitiska forskningsinstitutet. Där fortsatte hans forskningskarriär ända tills han gick i pension. Åren 1980-1996 fungerade han som institutets direktör.

Törnudds närmaste arbetskollega var under flera årtionden professor Inkeri Anttila (1916-2013), som fungerade som föreståndare för Kriminologiska forskningsinstitutet och direktör för Rättspolitiska forskningsinstitutet före honom. Deras samarbete och vänskap fortsatte ända till Anttilas död.

Patrik Törnudd reformerade på ett betydelsefullt sätt den kriminologiska teorin och det kriminalpolitiska tänkandet. Hans viktigaste artiklar har publicerats på engelska som samlingen Facts, Values and Visions. Essays in Criminology and Crime Policy (Edited by Inkeri Anttila et al., National Research Institute of Legal Policy, Publication no. 138, Helsinki 1996).

I denna samling är följande år 1969 ursprungligen publicerade artiklar särskilt betydelsefulla: On Defense of General Prevention; The Futility of Searching for Causes of Crime. De tankar som framfördes i dem utvecklade Patrik Törnudd i sin senare produktion och likaså $\mathrm{i}$ den lärobok som han uppgjorde tillsammans med Inkeri Anttila och vars svenskspråkiga version utkom under namnet Kriminologi i kriminalpolitiskt perspektiv (Norstedts, Stockholm 1973).

Inom kriminologin är det väsentligt att skilja mellan två nivåer med avseende på klarläggningen av brottslighet: variationer i brottslighetens mängd och struktur samt lagenligheter som påverkar vilka som utväljs till gärningsmän och brottsoffer. Brottslighet måste förstås som en växelverkan, där parterna utgörs av gärningsmannen, brottsobjektet och samhället. 
Granskningen av det officiella kontrollsystemets verksamhet och effekter är ett viktigt delområde inom kriminologin. Det straffrättsliga systemets roll inom brottsbekämpningen är begränsad. Den generalpreventiva effekt som eftersträvas med det straffrättsliga systemet förutsätter inte stränga straff, utan snarare et kontrollsystem som förstärker medborgarnas moraluppfattningar och uppfattas som legitimt samt ett påföljdssystem som är rättvist och tar proportionalitetsprincipen i beaktande.

I den nämnda läroboken är det centralt att sammankoppla den kriminologiska forskningen till det kriminalpolitiska beslutsfattandet. Inom kriminalpolitiken måste man sträva efter rationalitet, och en förutsättning för det är att man är medveten om åtgärders verkningar och alternativ till dem samt de värde- och intressedimensioner som hänför sig till valet av dem. Boken lade grunden för en förnyad kriminalpolitik och för straffrättens kunskapsmässiga och ideologiska reformering.

Under hela sin yrkeskarriär deltog Patrik Törnudd aktivt i lagberedningsuppgifter på straffrättens område. Hans viktigaste uppgift var medlemskapet i beredningsorganen för strafflagstiftningens totalreform: han fungerade som arbetsutskottets sekreterare och medlem i straffrättskommittén 1972-1976 och som medlem i ledningsgruppen för justitieministeriets projektorganisation (strafflagsprojektet) och de arbetsgrupper som fungerade under den 1980-1999.

Törnudds undersökning Kvalificerade förmögenhetsbrott de lege ferenda (Kriminologiska forskningsinstitutet, M:14, Helsingfors 1971) påverkade utformningen av brottsbeskrivningarna för den strafflag som skulle förnyas: brottstypernas kvalificeringsgrunder skulle vara uttömmande angivna, men en helhetsbedömning av de omständigheter som föranlett och framgick av brottet kunde leda till ett lindrigare resultat för den åtalade.

I strafflagens totalreform 1990-2003 koncentrerades straffbestämmelser med fängelsehot till strafflagen. Syftet med denna målsättning var enligt idéns fader, Patrik Törnudd, att »bromsa särinitiativ framförda av överentusiastiska populister«. Att motarbeta populism var centralt i hans tänkande, där han betonade kriminalpolitikens följdriktighet och planmässighet: kriminalpolitiken skulle »basera sig på systematisk kunskap, praktisk erfarenhet och humana värderingar« (Törnudd, NTfK 1985, s. 274 ff.).

Patrik Törnudds produktion och effekten av hans verksamhet begränsade sig inte till hans hemland. Han föreläste och publicerade mycket på sitt modersmål svenska samt på finska och engelska. Särskilt gärna deltog han i det nordiska samarbetet, bland annat genom att fungera som ordförande för Nordiska samarbetsrådet för kriminologi 1986-1988. 
Törnudd påverkade FN:s kriminalpolitiska funktioner bland annat som medlem i den finska delegationen vid FN:s kongresser på området och som medlem i rådgivande delegationen för Helsingfors kriminalpolitiska institut (HEUNI). I den resolution som godkändes vid FN:s kongress i Genève 1975 rekommenderades på Törnudds initiativ ett kostnad-nytta-medvetet tänkande och en rättvis distribution av kostnader inom kriminalpolitiken.

I sina framträdanden var Patrik Törnudd eftertänksam, han vägde analytiskt olika alternativ och avvisade ensidiga ställningstaganden. Till sin karaktär var Törnudd anspråkslös och okonstlad. För de som kände Törnudd närmare var han en hänsynsfull samtalspartner och en humorist. Som ett exempel på hans mångahanda hobbyn kan ges hans uppträdande som skådespelare i televisionen år 1969 i stycket Sjuk eller skyldig som skrevs av Ulf-Göran Ahlfors och Claes Andersson.

Törnudd såg med värme tillbaka på de smågrupper som utformade den allmänna opinionen under 1960-talet, som han själv också aktivt verkade i. Många av medlemmarna i dessa smågrupper blev senare kriminal- och rättspolitiska beslutsfattare, och effekterna av de professionella diskussioner som fördes i grupperna kom att synas i form av lagstiftningsreformer från och med 1970-talet. Törnudd ville ingjuta tro i en planmässig kriminalpolitik, trots att allt fler intresseinriktningar och värdeorienteringar försvagar uppnåendet av konsensus kring dess medel och om vad som utgör en framgångsrik brottsbekämpning. 